\title{
Implementation of ECHR decisions on expulsion in a modern digital society
}

\author{
Elvina Ablyakimova ${ }^{1}$, Vladislav Kostylev ${ }^{2}$, Artem Rudenko $^{1}$, Kristine Trifonova $^{2}$, and Sergey Trifonov ${ }^{1}$ \\ 1 Russian State University of Justice, Higher Educational Institution, Crimean Branch, Pavlenko Str. 5, 295000, Simferopol, Russia, e- \\ mail:rudenkocrimea@yandex.ru. \\ 2 Russian State University of Justice, Higher Educational Institution, Crimean Branch, Pavlenko Str. 5, 295000, Simferopol, Russia, e- \\ mail:rudenkocrimea@yandex.ru. \\ 3 Russian State University of Justice, Higher Educational Institution, Crimean Branch, Pavlenko Str. 5, 295000, Simferopol, Russia, e- \\ mail: kri-kazaryan@yandex.ru. \\ 4 Russian State University of Justice, Higher Educational Institution, Crimean Branch, Pavlenko Str. 5, 295000, Simferopol, Russia, e- \\ mail: sergey3fonov@yandex.ru
}

\begin{abstract}
The globalization of world economic relations, political instability and different levels of economic development in different countries predetermine a significant flow of migrants. The problem of illegal migration and application of measures of legal responsibility against migration legislation violators concerns most countries of the world. At the same time, applying such a sanction as expulsion, a number of states, including the Russian Federation, come into conflict with the legal positions of the European Court of Human Rights (hereinafter the ECHR) regarding expulsion of stateless persons and foreigners. The administrative expulsion, unfortunately, has not undergone any significant changes in the digital age, although the urgent need for such reform is obvious. It is emphasized in the legal positions of the ECHR that decisions on expulsion must be justified by pressing social necessity and they must correspond to a legitimate aim, since they may violate the right to respect the private and family life. It is necessary to take into account the legal positions of the ECHR in the framework of proceedings on expulsion and adhere to the principle of individualization of responsibility for an administrative offense, with taking into account the specific circumstances in each specific case.
\end{abstract}

\section{Introduction}

The migration policy of the Russian Federation is constantly undergoing reforms. In the policy formation, much attention is paid to regulation of processes related to the illegal stay of a foreign citizen on the territory of the Russian Federation, as well as to prevention of offenses committed by migrants. It is due to the fact that number of foreign citizens on the territory of the Russian Federation is growing rapidly, mainly due to the tense situation in the world. Caused by such factors, migration processes are becoming a negative phenomenon and a threat to the socio-economic and political development of states.

It seems that the migration policy in the context of a modern information society can become more effective through the use of modern digital technologies within the framework of the regulation of migration activities, which will allow to more effectively implement state policy in this area..

\section{Problem Statement}

Violation of migration rules is characterized by high latency and their sudden onset, and, therefore, it is almost impossible to determine the exact number of migrants appearing on the territory of the Russian Federation. Most foreign citizens and stateless persons enter the Russian Federation legally, but they lose the grounds for staying during their long stay in the Russian Federation and, as a result, they are recognized as illegal migrants later.

Based on the above, the conclusion follows that the control over illegal migration by the state should be strengthened. Expulsion is recognized as one of the most effective and promising mechanisms for combating persons violating the migration regime.

Since adoption of the Code of Administrative Offenses of the Russian Federation [1] in year 2001, the legal regulation of the procedure for the administrative expulsion of foreigners and stateless persons from the Russian Federation has not undergone any significant changes. The very concept of expulsion has not changed during 19 years of the law implementation; it is defined as a forced and controlled movement of foreigners and stateless persons across the State border of the Russian 
Federation outside the Russian Federation, and in cases provided for by the legislation of the Russian Federation, it is a controlled independent departure of foreign citizens and stateless persons from the Russian Federation.

\section{Research Questions}

The main amendments in the legal regulation of the expulsion procedure were introduced by Federal Law No. 410-FZ "On Amendments to the Federal Law On Bailiffs and Certain Legislative Acts of the Russian Federation" [2] dated 06.12.2011. They touched upon the definition of the authority entitled to choose the form of expulsion, the possibility of keeping persons who are assigned for expulsion in special detention centers, as well as determining the conditions where it is possible to apply expulsion in the form of the immigrant's independent controlled exit. Thus, the amendments only specified those provisions that were contained in the Code of Administrative Offenses of the Russian Federation (hereinafter referred to as the Code of Administrative Offenses) earlier.

The procedure for the execution of an administrative penalty in the form of expulsion did not undergo any significant changes during the specified period either.

The problems of imposing an administrative penalty in the form of administrative expulsion, existing at the moment, and the problems of its implementation should be resolved with the adoption of the new Code of Administrative Offenses of the Russian Federation.

In the draft Code of Administrative Offenses of the Russian Federation submitted by the Government of the Russian Federation [3], the concept of "administrative expulsion" is defined similarly to the current version of the Code, which may indicate the legislator's unwillingness to change the current situation. At the same time, Article 3.27 of the Draft, dedicated to the Rules for the appointment of an administrative penalty in the form of administrative expulsion, makes a significant step towards guaranteeing rights of expelled persons. It contains cases when it is impossible to impose an administrative expulsion. They include:

1. When the expelled person has a child who is a citizen of the Russian Federation and permanently resides in the Russian Federation;

2. When the expelled person has a status of a refugee or a person holding temporary asylum;

3. Arrival of a person on the territory of the Russian Federation in an emergency mass order;

4. Recognition of a person as a compatriot.

The emergence of such a provision in the Draft indicates that the Russian authorities are taking into account modern approaches in the migration policy. At the same time, it is worth noting that not all the positions expressed by the ECHR in its decisions were reflected in the Draft.

In addition to changing the procedure for applying administrative expulsion, it is worth paying attention to the composition of administrative offenses containing this type of punishment.
According to a number of scientists, including V.P. Soldatov, it is necessary to amend the wording of the sanction of clause 1.1., Art. 18.8 of the Administrative Code of the Russian Federation at the federal level, providing in it not only the main punishment and additional punishment in the form of a fine and compulsory administrative expulsion, but also a possibility of not applying additional punishment (expulsion) to the offender. They could use the following wording: after the words "... with administrative expulsion outside the Russian Federation", add the phrase "or without it". The scientific research has clearly shown that today there are sufficient grounds not to apply that additional punishment (the international legal act, the judgments of the Constitutional and Supreme Courts), but very few people know about them at the level of city and district courts of law, and judges are not guided by them. How much effort, means and other costs were required for offenders to receive lawful and fair court judgments. In this regard, some other, more ambitious, conclusions and proposals [4] can be done.

The administrative expulsion of a foreign citizen or stateless person outside the Russian Federation can be established and applied as both the main and additional administrative punishment (part 2, article 3.3, Code of Administrative Offenses of the Russian Federation).

The decisions of the Supreme Court of the Russian Federation have repeatedly noted that the application of additional punishment in the form of administrative expulsion from the Russian Federation should be based on data confirming the need to apply that measure of responsibility to the violator as the only possible way to achieve a fair balance of public and private interests within the framework of administrative proceedings.

Within the meaning of the provisions of the Convention for the Protection of Human Rights and Fundamental Freedoms [5], which entered into force for Russia on May 5, 1998, and the Convention on the Rights of the Child [6] (adopted on November 20, 1989), which entered into force for the USSR and for its legal successor, the Russian Federation, on 15 September 1990, and in view of their application by the European Court of Human Rights, the expulsion of a foreign citizen or a stateless person outside the Russian Federation, entailing an interference with the right to respect for private and family life, shall be allowed only in cases where it is necessary in a democratic society and in proportion to public law goals.

Ratifying the Convention, the Russian Federation recognized the jurisdiction of the European Court of Human Rights as binding on interpretation and application of the Convention and its Protocols in cases of alleged violation by the Russian Federation of any provisions of those treaty acts [7].

However, it's necessary to put an emphasis on the latest amendments altered into the Constitution of the Russian Federation. Article 79 of the Constitution of the Russian Federation, set forth in the new edition, indicates that "the Russian Federation may participate in interstate associations and transfer to them part of its powers in accordance with international treaties of the Russian Federation, if this does not entail any 
restrictions on the rights and freedoms of man and citizen and does not contradict the foundations of the constitutional system of the Russian Federation. Any decisions of interstate bodies adopted on the basis of the provisions of international treaties of the Russian Federation in their interpretation, contrary to the Constitution of the Russian Federation, shall not be subject to execution in the Russian Federation" [8]. Therefore, if any decisions of the ECHR contradict the Constitution of the Russian Federation, they will not be enforced on the territory of Russia.

It is clear from the clarifications of the Plenum of the Supreme Court of the Russian Federation in Resolution No. 23 "On Judgment" dated December 19, 2003, Paragraph 4, that the court should take into account, along with the norms of the substantive law, the decisions of the European Court of Human Rights, which provide an interpretation of the provisions of the Convention for the Protection of Human Rights and Fundamental Freedoms to be applied in the case.

It is necessary to analyze the jurisprudence of the ECHR in cases of administrative expulsion.

The analysis of the decisions taken by the European Court of Human Rights in cases of administrative expulsion, carried out by E.O. Bondar, allows us to speak of the following violations of Art. 3 and 5 of the Convention for the Protection of Human Rights and Fundamental Freedoms of 1950 (hereinafter - the Convention) [5]:

- in some cases, expulsion is replaced by extradition or deportation;

- Art. 3 of the Convention is violated ("forcible return to a country where the applicant is at risk of torture and prohibited treatment or punishment") (also in the context of the execution of court orders that have entered into force);

- the person's freedom is restricted unreasonably (inconsistency with the purpose, where expulsion cannot be carried out; this applies especially to stateless persons) [9].

In our opinion, violations of Article 8 of the Convention should be added to this list.

Let us consider that category of cases in more detail.

The European Court of Human Rights has concluded that the Convention does not guarantee foreigners the right to enter into or to reside in a particular country and not be expelled, having noted that the state's responsibility for ensuring public order obliges the state to control entry into the country; at the same time, decisions in this area must be justified by pressing social necessity, since they may violate the right to respect for private and family life, protected in a democratic society by Article 8 of the named Convention, and they should correspond to a legitimate aim (Case 'Berrehab v. the Netherlands', dated 21 June 1988, §28; 'Boughanemi v. France', dated 24 April 1996, §41; 'El Boujaidi v. France', dated 26 September 1997, §39; 'Uner v. the Netherlands' of 18 October 2006,§54; Liu and Liu v. Russia, dated 6 December 2007, §49; Decision of 9 November 2000 on admissibility of the complaint "Andrey Shebashov v. Latvia" and others.) [10].
With regard to criteria for the admissibility of expulsion taking place in a democratic society, the European Court of Human Rights noted that the importance attached to one or another of them will differ depending on the circumstances of a particular case; bound by the need to establish a fair balance between the competing interests of the individual and society as a whole, the state has certain margin of appreciation; at the same time, the authorities' right to apply expulsion can be an important means of preventing serious and repeated violations of the immigration law, as leaving those violations unpunished would undermine respect for the immigration law.

According to the legal position of the European Court of Human Rights, the totality of social ties between migrants and the society where they live is included in the concept of "private life" in the sense of Article 8 of the Convention for the Protection of Human Rights and Fundamental Freedoms; thus an expulsion of a settled (resident) migrant, regardless of availability or absence of his "family life" could lead to a violation of the right for his "private life" ('Uner v. the Netherlands' of 18 October 2006, §59; 'Alim v. Russia' dated 27 September 2011, § 68).

Assessing the circumstances in which the expulsion of a foreigner gives rise to a violation of Article 8 of the Convention for the Protection of Human Rights and Fundamental Freedoms, the European Court of Human Rights uses the criteria of the necessity of such a measure in a democratic society and its proportionality to the legitimate aim pursued: the nature and severity of the offense committed by the person, and the length of his stay in the country and his behavior, including attempts to legitimize his residence, and citizenship of the persons concerned, and the characteristics of the family life of the immigrant, including availability of children from his marriage and their number, and difficulties that a spouse is expected to face in the country where his spouse, an immigrant, is being expelled, and availability of insurmountable obstacles for a family to live in their home country for one of the spouses, etc.

With regard to the Russian Federation, the European Court of Human Rights noted the difference between what it considers insignificant violation of the rules of registration of foreigners and staying in the country without such a document as a visa or a permit (Resolution in 'Alim v. Russia' dated 27 September 2011, §78, 87 and 89) [11].

Pursuant to the Resolution of the European Court in case 'Alim v. Russia' dated 27 September 2011, (Complaint No. 39417/07, § 81), Article 8 of the Convention does not impose a general obligation on the state to respect the immigrant's choice of the country of residence and to authorize the re-establishment of families on its territory. However, in matters relating to the family life and immigration, the extent of the state's duty to admit relatives to persons staying in its territory will depend on the specific circumstances of those persons and their main interests.

In the judgment of the European Court in the case Zakayev and Safanova versus Russian Federation' 
(Complaint No. 11870/03, §41), The Court notes that a number of relevant criteria have been developed in the case 'Boultif v. Switzerland' (Complaint No.54273/00, $\S 48$ ), which should be used in assessing whether the expulsion is a necessary measure in a democratic society and whether the expulsion is proportionate to the legitimate aim pursued. [12]

Those criteria, inter alia, are: citizenship of the interested persons; the applicant's family situation, in particular, the length of their marriage and other factors indicating reality of the couple's family life; whether the spouse knew about such violation at the time of entering into the family relationships.

Within the meaning of Article 8 of the Convention, the aspect of presence or absence of "the family life" is mainly a matter of fact, which depends on actual existence of close family relations. The concept of "family life" is autonomous, i.e. does not depend on how it is understood in the national legislation of any state. According to the case-law of the European Court of Justice, the concept of family is not limited to a registered marriage and it shall also include a de facto marriage relationship. Any child born out of such a relationship shall be ipso jure a part of that family unit from the moment of birth and by the very fact of his birth. Thus, there is a connection between the child and his parents, equal to family life (Judgment of the European Court in the case 'The case of Guliyev and Sheyna v. Russia' (Complaint No. 29790/14) [13].

\section{Purpose of the Study}

The purpose of the scientific research is, on the basis of the available scientific data of the theory of state and law, international law, constitutional law, administrative law, labor law, the practice of public authorities, to consider topical issues of the implementation of the positions of the ECHR on the expulsion of foreigners in the context of modern digital society.

\section{Research Methods}

The methodological basis of scientific research consists of general scientific (analysis and synthesis, comparison, description, generalization, modelling) and specific scientific (comparative legal, legal modelling, formal legal, document analysis) methods.

\section{Findings}

Various approaches have been identified within the framework of the judicial practice of the Supreme Court of the Russian Federation and the ECHR regarding the procedures of administrative expulsion in terms of replacing it with extradition or deportation, violation of a number of norms of the Convention for the Protection of Human Rights and Fundamental Freedoms of 1950. At the same time, in some cases, the similarity of the legal positions of the Constitutional courts of the Russian
Federation and the ECHR on research issues has been identified.

The need to strengthen the digital component in the processes of regulating migration activities has been noticed.

\section{Conclusion}

The position of the European Court is confirmed by its new judgments.

In particular, in the case Akopdzhanyan v. Russia (Application no. 32737/16) [14], the gist of which was that the applicant complained that his expulsion from the Russian Federation, with an eight-year re-entry ban, violated his right for the family life, The European Court decided unanimously that the Russian Government had violated the requirement of Article 8 of the Convention (the right to respect for private and family life) in that case.

In one case, the administrative expulsion from the country may be regarded as an interference with the person's right to family life, which, however, does not entail a violation of this article as long as it is justified within the meaning of paragraph 2 , Article 8 of the Convention, and in other case, it can be regarded as a violation of Article 8 of the Convention.

The legal positions of the Constitutional Court of the Russian Federation on similar cases coincide in many respects with the opinion of the European Court of Human Rights. "When it comes to institutions related to termination of the stay or residence of a foreign citizen in the Russian Federation, including administrative expulsion from its territory, the courts of law should not limit themselves to establishing only formal grounds for application of the law, they must investigate and assess the real circumstances in order to recognize that the appropriate decisions in respect of a foreign citizen are necessary and proportionate ... " [15]

There is a significant number of Resolutions of the Supreme Court of the Russian Federation on abolition of judgments on bringing foreign citizens to administrative responsibility with their expulsion outside the country in connection with failure of judges to take into account the actual circumstances of committing those administrative offenses, due to availability of spouses and children of migrants residing on the territory of Russia, who have received citizenship in the manner prescribed by the law.

The Resolutions of the Supreme Court are based on the position of the European Court of Human Rights reflected in the Decision No.39428/12 in the case "Gablishvili v. Russia" of June 26, 2014 [16]. Based on the results of consideration of Gablishvili's complaint, the refusal to allow the foreign citizen to enter Russia was found to be contrary to Article 8 of the Convention for the Protection of Human Rights and Fundamental Freedoms [17], which guarantees everyone the right to respect for his personal and family life in connection with the permanent residence of his wife and children, citizens of Russia, in one of the territories of the Russian Federation. 
Based on the foregoing, we should note that the Supreme Court of the Russian Federation has repeatedly made the resolutions cancelling judgments of the lower courts on bringing foreign citizens to administrative responsibility regarding their expulsion from the territory of Russia, thereby calling into question the effective decisions of the authorized bodies not to allow foreigners to enter into the territory of the country.

In our opinion, certain organizational and legal measures are needed to resolve the current problem. It seems necessary to strengthen the state mechanism for protecting the rights of migrants. In particular, one of the measures may be establishment of a high-quality judicial control over defense of migrants' rights, especially in implementation of the provisions of the Convention. It is necessary to focus on the fact that in order to prevent, detect and suppress violations of the migration legislation of the Russian Federation, the application of administrative measures in this area, the use of modern digital technologies and information and technical means is becoming increasingly important, as well as for improving the mechanisms for obtaining by interested state bodies the information on the presence of foreign citizens in the Russian Federation, their movement across its territory, expanding the use of modern biometric technologies for personal identification, ensuring effective control over compliance with the requirements of the labor legislation of the Russian Federation on taxes and fees by employers who engage and make use of foreign workers.

Summing up, it is necessary to note that when exercising their sovereign rights in the field of migration policy, the state authorities should take into account the legal positions of the ECHR. The procedure for bringing to administrative responsibility entailing a penalty in the form of administrative expulsion, must provide substantial procedural guarantees, and must be applied on the basis of the principle of individualization of responsibility for the committed administrative offense, where the competent authorities must take into account the circumstances of each specific case [18].

\section{References}

1. Code of the Russian Federation on Administrative Offenses dated 30.12.2001 No. 195-FZ, Collected Legislation of the Russian Federation of year 2002, No.1, Art. 1

2. Federal Law No. 410-FZ "On Amendments to the Federal Law on Bailiffs and Certain Legislative Acts of the Russian Federation", Collected Legislation of the Russian Federation, 12.12.2011, No. 50, Art. 735.

3. Draft of the Federal Law - Code of the Russian Federation on Administrative Offenses,

URL: https://regulation.gov.ru/projects\#sear $\mathrm{ch}=02 / 04 / 05-$

20/00102447\&npa $=102447$ (date of access 02.12.2020)

4. A.P. Soldatov, Works of the Academy of the Ministry of Internal Affairs of Russia 4 (48), 191-193 (2018)

5. SPS Consultant Plus, Bulletin of International Agreements 3 (2001)

6. SPS Consultant Plus, Convention on the Rights of the Child (approved by the UN General Assembly on November 20, 1989 and entered into force for the USSR on September 15, 1990) (1990)

7. SPS Consultant Plus, Federal Law No.54FZ "On Ratification of the Convention for the Protection of Human Rights and Fundamental Freedoms and Protocols thereto" dated March 30, 1998 (1998)

8. New text of the Constitution of the Russian Federation with the 2020 amendments, http://duma.gov.ru/news/48953/ (date of access 12.12.2020)

9. Ye.O. Bondar, Bulletin of the Barnaul Law Institute of the Ministry of Internal Affairs of Russia 1(30), 58-59 (2016)

10. Judgment of the European Court of Human Rights of July 26, 2011 Case "Liu v. Russian Federation (No.2)" (Application No.29157/09) (First section), Bulletin of the European Court of Human Rights 8 (2012)

11. Judgment of the ECHR dated 27.09.2011 - 'Alim v. Russian Federation' (Application No.39417/07), Bulletin of the European Court of Human Rights 2 (2013)

12. Judgment of the ECHR of 11.02.2010 Case "Zakayev and Safanova v. Russian Federation" (Application No. $11870 / 03)$, Bulletin of the European Court of Human Rights 8 (2010)

13. Judgment of the ECHR of 19.06.2008 Case "Guliyev v. Russian Federation" (application No. 24650/02), Russian Chronicle of the European Court 2 (2009)

14. Akopdzhanyan v. Russia (Application No. $\quad 32737 / 16)$, URL: 
http://www.echr.coe.int> (date of access: 12.12.2021)

15. RLS Consultant Plus, Resolution of the Constitutional Court of the Russian Federation No.5-P of February 17, 2016 "On Inspection of Constitutionality of provisions of the Federal Law "On Legal Status of Foreign Citizens in the Russian Federation", Article 8, Paragraph 6, and Parts 1 and 3 of Article 18.8 of the Code of Administrative Offenses of the Russian Federation, and the Federal Law "On the procedure for leaving the Russian Federation and entering the Russian Federation", Part one of Article 27, Subparagraph 2, in connection with the complaint of M. Turcan, citizen of the Republic of Moldova (2016)

16. Judgment of the ECHR of 26.06.2014 Case 'Gablishvili v. Russian Federation' (Application No. 39428/12), Precedents of the European Court of Human Rights 2 (152) (2015)

17.D. Strazzari, European Journal of Migration and Law, 114-138 (2020)

18. A. Aranguiz, M. Quené, European Journal of Migration and Law, 509-539 (2019) 